Research Article

Araştırma Makalesi

https://doi.org/10.46452/baksoder.710575
USOBED Uluslararası Batı

Karadeniz Sosyal ve Beşeri

Bilimler Dergisi, 4(1): 66-86

30 Haziran-June, 2020
International Journal of

Western Black Sea Social and

Humanities Sciences

e-ISSN :2602-4594

\title{
DINI CEMAATLERIN DEMOKRASI ALGISI ÜZERINE MUKAYESELI BIR ÇALIŞMA; NUR HAREKETI VE MÜSLÜMAN KARDEŞLER ${ }^{1 *}$
}

\author{
Prof. Dr. Mahmut BOZAN
}

Bartın Üniversitesi İİBF Siyaset Bilimi ve Kamu Yönetimi Bölümü

mbozan@bartin.edu.tr

Orcid: 0000-0002-5936-7021

$\ddot{O} \mathbf{z}$

Osmanlı Devleti 1. Dünya Harbi sonunda dağılmış ve Devletin iki temel Müslüman unsuru olan Türkler ve Araplar ayrılmışlardır. Bu ayrılış daha sonra rejim faklılaşması ve diğer sebeplerle kısmi bir yabancılaşmaya dönüşmüştür. Türkiye'nin Avrupa ulus-devlet modeline uygun Batılı bir kimlik benimsemesi ve İslâm dünyasına arkasını dönmesi, başta Mısır olmak üzere bazı Arap devletlerinin otoriter Baas milliyetçiğini esas alması ayrışmayı daha da derinleştirmiştir. Devlet politikalarında Batı temelli ve sosyal ağırlıklı modernleşme hareketlerinin toplumda tam bir karşılığı olmadığı için ikinci bir ayrışma da halk ile devlet arasında yaşanmaya başlamıştır. Bunun sonucunda hem Türkiye'de, hem de Arap ülkelerinde meşruiyetini halktan almayan, Batı destekli ve güce dayalı otoriter rejimler ortaya çıkmıştır. Batılı ülkelerin bu rejimlere destek vermesinin esas sebebi şüphesiz siyasî, askeri ve daha önemlisi iktisadi menfaatleri ve sömürge siyasetleridir.

Devletler düzeyinde bu politikalar güdülürken, halklar ise tevarüs ettiği tarihi kimliği ve beslendiği inanç değerleri esas alarak daha farklı bir gelişim çizgisi takip etmiştir. Bu konuda ülkeden ülkeye farklılıklar olmakla birlikte Türk ve Arap toplum yapısında iki hareket oldukça dikkat çekmektedir. Bunlardan birisi Araplardaki İhvan-ı Müslim'in, diğeri ise Türkiye'deki Nur Cemaatidir. Bu çalışmada bu iki hareketin temel dinamikleri, benzerlik ve farklılıkları ile siyasî yapının dönüşümüne katkıları mukayeseli olarak incelenecektir.

Anahtar kelimeler: İhvanı Müslimîn, Nur Cemaati, Arap Baharı.

\section{A COMPARATIVE STUDY ON THE PERCEPTION OF DEMOCRACY OF RELIGIOUS COMMUNITIES; NUR COMMUNITY AND MUSLIM BROTHERS}

\begin{abstract}
The Ottoman Empire distributed after the end of World War I and the Turks and Arabs that were two basic Muslim elements of the State were divided. Then, this departure became a partial alienation because of regime differentiation and other reasons. Turkey's adoption of Westerner identity that is appropriate to European nation-state model, and the back of the rotation to the Islamic World, and finally Arab states including especially Egypt based on the Baath Party further deepened the cleavage. The second separation began to experience between the state and the people because in the State Policies, Western-based and modernization movements which were largely about social were no compensation in society. As a result, authoritarian regimes whose legitimacy did not base on the public were Western-backed and power-based emerged both in Turkey and the
\end{abstract}

\footnotetext{
${ }^{1}$ Bu makale 22- 24 Kasım 2018 tarihinde Antalya'da yapılan “Innovation and Global Issues in Multidisciplinary Sciences IV" Kongresinde sunulan sözlü bildirinin gözden geçirilerek yeniden yazılmış halidir.

*Sorumlu Yazar (Corresponding Author)

Citation/Atıf: Bozan, M. (2020). Dini Cemaatlerin Demokrasi Algısı Üzerine

Mukayeseli Bir Çalişma; Nur Hareketi ve Müslüman Kardeşler. Uluslararası Batı

Karadeniz Sosyal ve Beșeri Bilimler Dergisi, 4 (1), 66-86. DOI:

Geliş (Received) : 28.03.2020

10.46452/baksoder.710575 
Arab Countries. The main reason for supporting these regimes by Western Countries, undoubtedly, is political, military and economic interests and more importantly, their colonial politics.

While in the states level these policies were executed, peoples that were inheriting their historic identity and nurturing religion values followed a different line of development. Although there were differences from country to country on this subject, two movements attracted attention in the structure of the Turkish and Arab society. One of them is the Muslim Brotherhood in Arab societies, the other one is the Nur Community in Turkey. In this study, the basic dynamics and the similarities/differences of these two movements, and the contributions to the transformation of the political structure will be examined in a comparative way.

Keywords: The Muslim Brotherhood, Nur Community, Arab Spring.

\section{Giriş}

Sovyetler Birliği'nin dağılması ve demir perdenin çökmesi ile ortaya çıkan belirsizlikler, aradan geçen 30 yıl içinde ortaya yeni bir tablo koymuştur. Batı felsefesinden beslenen faşizm gibi Marksizm de ortadan kalkmış, kapitalizm ise ölümcül bir kriz ortamına sürüklenmiştir. Artık Batı tek güç de değildir, rakipsiz de değildir. Sanayi devriminin emperyal ve emperyalist gücünü temsil eden Batı, bilgi çağının başlaması ve bilgi toplumunun ortaya çıkması ile ulaştığı tepe noktasından inişe geçmiştir. Dünyanın güç merkezi Asya'ya kaymaktadır. Şüphesiz bunun Dünya siyasetinde önemli tesiri ve akisleri olacaktır. Her ne kadar soğuk savaş döneminin BM, IMF ve Dünya Bankası gibi yapıları ile bunlarla paralel olarak hareket eden işbirlikçi "uluslararası kuruluşları" Batıyı ayakta tutmak için çaba harcıyor olsalar da sonuç değişecek gibi görünmemektedir. Batı tarafından sömürgeleştirilen ve kaynakları yağmalanan ve kısmı âzamını Müslümanların oluşturduğu devletlerde ciddi bir uyanış hareketi başlamıştır. Bu hareket, birinci dalgada Batı ile bütünleşen doğu Avrupa'dan farklı olarak kendi kimliğine dönme, ikincisinde ise kendi mecrasında akma istidadı gösteren ve Arap Baharı olarak adlandırılan harekettir.

Batı önce bu hareketi kendi lehine çevirmeye ve kontrol altına almaya yönelmiş, fakat bunu başaramayacağını anlayınca Suriye örneğinde görüldüğü üzere hareketi rayından çıkarma, dâhili bir kutuplaşma ve iç savaş zemini oluşturma gibi alternatiflere yönelmeye başlamıştır. Özellikle Arap Baharı'nın iki yüz yıldır toparlanamayan İslam birliğinin yeniden inşasına zemin teşkil etme ihtimali ve bu süreçte Türkiye'nin oynayacağı tarihi rol, Suriye üzerinden Türkiye'yi vurma arzusunu daha bir kuvvetlendirmiş gözükmektedir. Ancak bu beyhude bir hareketten öte bir istidat taşımamaktadır. Çünkü zemin ve zaman değişmiş, yeni dinamikler ve yeni "mega trendler" devreye girmiştir. Batı medeniyeti yerini finans tekellerinin insanlığı açlığa mahkûm etmediği, sömürü ve zulmün olmadığı, huzur ve barışın hâkim olacağı bir medeniyete teslime hazırlanmaktadır. 
$\mathrm{Bu}$ kuru bir temenni veya niyetten ibaret değildir. Tersine, Osmanlı Devleti'nin ortadan kaldırılması ile dağılan İslam Birliğinin yeniden inşasını sağlayacak güçlü taban hareketlerinin tabii bir sonucudur. Bu makalede İslam birliğinin iki temel unsuru olan Türk ve Arap dünyasındaki bu taban hareketleri ile bu hareketlerin kullandığı metotlar mukayeseli olarak incelenecek ve İslam dünyasının bu "en uzun fetreti" nin neden daha fazla devam edemeyeceği açıklanmaya çalışılacaktır.

\section{Osmanlı Devleti’nin Dağılmasıyla Ortaya Çıkan Durum}

Osmanlı Devleti'nin son dönemlerinde Batı'nın iktisadi, askeri ve teknolojik üstünlüğüne karşı idame yi vücut için aranan yollardan Osmanlılık aidiyeti ve İslam birliği gerilerken, batıcılık ve milliyetçilik fikirleri öne çıkmaya başlamıştır. Daha sonra milliyetçilik İslam yerine ikame edilmek ve temelde ise Batılı değerleri "tüm kurum ve kuralları ile" almaya yönelik bir akım siyasî gücü ele geçirmiştir. Osmanlı Devleti'nin yerine kurulan Türkiye'de bunlar olurken, Batı'nın sömürgesi haline gelen ve bilahare bağımsızlığını kazanan diğer İslam ülkelerinde ve bilhassa Araplarda da milliyetçi akımlar güç kazanarak totaliter ve otoriter rejimler ortaya çıkmıştır.

Osmanlı bakiyesi olarak değerlendirilen bu ülkeler içinde şüphesiz diğerlerini açıkgizli etkileyen ve Osmanlı'nın varisi olan Türkiye'de tüm dünyayı şaşkına çeviren hareketler meydana gelmiştir. Saltanatın kaldırılması ve akabinde Hilâfetin ilgası ile Türkiye, İslam dünyasındaki müessiriyetinin en güçlü araçlarını feda etmiştir. Sanki bunların yerine 1876'dan beri tekâmül ederek gelen anayasalı, parlamentolu, seçimli ve döneminin şartlarına göre iyi sayılacak bir meşrutiyetten daha iyi olmayan bir otoriter rejim kurulmamış gibi, saltanat ve hilâfet hakkında tek kelime konuşulmasını "en büyük günah" gibi telkin eden psikolojik bir ortam oluşturulmuştur. $\mathrm{Bu}$ durum kısmen bugün bile geçerlidir. Oysa aynı çevreler tarafından Britanya'da kilise ile krallığı bünyesinde birleştiren taç yere göğe sığdırılamamakta ve İngiltere’ye “demokrasinin beşiğì” iltifatları yapılmaktadır.

Devletin yapılandırılmasında Fransız ulus-devlet modeli, Batı hukuk sistemi ile birlikte dini kontrol altına alan bir laiklik anlayışı ve Latin harflerinin kabulü, Osmanlıcanın yasaklanması ve sosyo-kültürel hayatın kılık-kıyafete kadar tek tipleştirici uygulamaları ile otoriter bir rejim inşa edilmiştir. Muhalefet sadece siyasî alanda ortadan kaldırılmamış, hayatın her safhasında muhalif bir görüşe, duruşa ve davranışa müsaade edilmemiştir. $\mathrm{Bu}$ hususta en küçük hareketler bile en şiddetli şekilde cezalandırılmış, "Takrir-i sükûn" muhalifler üzerinde bir giyotin gibi çalıştırılmış, mesela Şapka İktisası Hakkında Kanun (Resmî Ceride: 22.12.1341, Sayı: 230, No: 871) çıkmadan bir yıl önce yazdığı eser gerekçe gösterilerek bir bilim adamı "şapka uğruna" asılabilmiştir. 
Demokrasinin kaldırılarak yerine totaliter bir yap1 konulmas1, temel hak ve hürriyetlerin yasaklanmasına karşı toplumda iki tür muhalefet hareketi ortaya çıkmıştır. Bunlardan birincisi güce ve silaha dayalı isyan hareketleri, diğeri ise fikrî ve siyasî muhalefet hareketleridir. Türkiye'de güç kullanmaya yönelik isyan hareketlerinden en önemlileri 1925 yılında patlak veren Şeyh Said isyanı ile 1937 yılında çıkan Dersim isyanıdır. Siyasî hareketlere örnek ise Terakkiperver Cumhuriyet Fırkası ile güdümlü Serbest Firka hareketleridir. Hukukî zeminde mücadelenin imkânsızlı̆̆ı; özellikle tekke ve zaviyelerin kapatılması, ezanın asliyetinin tağyiri ve Türkçe okutulması, haccın, Kur'an öğrenmenin, dini tedrisatın yasaklanması sonucu dini hareketler ya ortadan kalkmış veya "yer altına" inmiştir. İşte bunlar içinde çalışmamıza konu olan "Nur hareketi" 1925 yılında Şeyh Said isyanına katılmadığı, bilakis karşı olduğu ve ikamet ettiği Van'daki aşiretlerin de isyana katılmasına mani olduğu halde Isparta'da mecburi ikamete tabi tutulan Said Nursi tarafindan telif edilen ve "Risalei Nur Külliyatı" olarak bilinen eserleri okuyan kişilerin fikri birlikteliği ile ortaya çıkmıştır.

Yine çalışmamıza konu olan ve menşe olarak Mısır'da ortaya çıkıp bilahare tüm Arap ülkelerinde zemin bulan “İhvanı Müslimîn” veya diğer adıyla "Müslüman Kardeşler” de 1928 yılında Hasan el-Benna tarafından Mısır'ın İsmailiye şehrinde dini hüviyeti olan siyasî bir teşkilat olarak kuruluştur. Türkiye ve Arap ülkelerinde şüphesiz siyasî, dini ve fikri muhalefet hareketleri çeşitlilik gösterir fakat İhvan ve Nur hareketi çalışmaları, temel esasları ve tesirleri itibariyle ciddiyetle üzerinde durulmayı hak etmektedirler.

\section{Nur Hareketi ve Said Nursi}

Bugün Nur hareketi olarak bilinen camia Bediüzzaman Said Nursi'nin² telif ettiği Nur Risalelerini okuyan, hareket tarzlarını da o eserlerdeki esaslara göre tanzim eden kişilerin bir araya gelmesi ile ortaya çıkmıştır. ${ }^{3}$

\footnotetext{
2 Bediüzzaman Said Nursî, 1878'de Bitlis vilayetine bağı Hizan ilçesi Nurs köyünde doğdu. 1900'lü yılların başında, doğuda Medresetü-z Zehra adında, din ve fen ilimlerinin birlikte okutulduğu bir İslam Üniversitesi kurmak fikriyle ülkenin yönetim ve hilafet merkezi olan İstanbul'a geldi ve hayatı boyunca bu fikrini gerçekleştirmek için gayret gösterdi. 1. Dünya Savaşı yıllarında doğu cephesinde gönüllü alay komutanı olarak hizmet etti. Savaş esnasında yaralanıp 2,5 yıl Rusya'da esir kaldı. 1917'deki Bolşevik ìhtilali esnasındaki kargaşadan yararlanıp esaretten kurtuldu. Dönüşte, Genelkurmay'ın kontenjanından Osmanlı'nın en üst düzey dinî danışma merkezi olan Dar-ül Hikmeti'l-İslamiyye'de görev yaptı. İngilizlerin İstanbul'u işgali yıllarında onların aleyhinde Hutuvat-ı Sitte adıyla bir risale neşretti. Anadolu'da başlatılan i̇stiklâl mücadelesine destek verdi. 1925 yılında Van'da eğitim faaliyetlerinde bulunduğu sırada meydana gelen Şeyh Said hareketi sebebiyle, bu harekete karşı çıktığı halde tedbir olarak önce Burdur'da, ardından Isparta ve Barla'da mecburi ikamete tabi tutuldu. Risale-i Nur isimli Kur'an tefsirinin çoğu bölümlerini burada yazdı. Eserleri ve fikirleri sebebiyle Eskişehir Mahkemesine sevk edildi. Sürgüne gönderildiği Kastamonu'da eserlerini yazmaya devam etti. 1943'te Denizli Mahkemesi'ne, 1948 'de Afyon Mahkemesi'ne sevk edildi. Mahkemeler beraatla neticelendi. 1950'de çok partili
} 
Cumhuriyetin ilk yıllarında Said Nursi hakkında görüş ortaya koyanlar öncelikle mahkeme ve onların talepleri ile görüş hazırlayan ehli vukuf olmuştur. O dönemde mesele asayiş mülahazaları açısından ele alınmakta ve en küçük muhalif tavır en sert şekilde cezalandırılmaktadır. Bu sebeple bazen akademik camiadan, bazen Diyanet uzmanlarından Said Nursi tarafından telif edilen ve Risale-i Nur olarak adlandırılan eserlerin asayişi ihlal, tarikat veya cemiyet kurma, mevcut rejime karşı tavır ortaya koyma açılarından değerlendirilmesi istenilmiştir. $\mathrm{Bu}$ amaçla hazırlanan ehli vukuf raporlarında Risale-i Nurlarda menfi bir durum tespit edilemediği, eserlerde daha ziyade iman hakikatleri üzerinde durulduğu ve güzel ahlâka yönelik tavsiyeler olduğu yönünde kanaatler ortaya çıkmıştır.

Cumhuriyetin tek partili döneminde siyasî iktidarların sürekli Bediüzzaman ve Risale-i Nurlarla uğraşmaları, gazete ve radyolarda takibât, tevkifât, mahkeme ve hapis gibi ceza haberlerinin duyulması sadece manevi açlığını dindirmek isteyen dindar halkın değil, eğitimli kesimlerin de dikkatini çekmeye başlamıştır. Özellikle dini neşriyatın yasak olduğu bu dönemde elle çoğaltılmak suretiyle dağılan Risale-i Nurlar ülke çapında bir fikir akımının doğmasına ve genişlemesine yol açmıştır.

Konu üzerine yazılan biyografi ve hatıralar, akademik çalışmalar ve ilmi konferans ve toplantılar daha çok kesimlerin Bediüzzaman ve Risale-i Nurlarla ilgilenmesini sağlamıştır. Tüm bunlar Said Nursi'nin bilinmeyen veya bilinmesi istenilmeyen çok yönlü kişiliğini, daha önemlisi İslam Dünyası için vazgeçilmezliğini ortaya çıkarmıştır.

Türkiye'nin son dönemdeki önemli fikir adamlarından Cemil Meriç'in tavsiyesi üzerine konuya eğilme lüzumunu hissettiğini söyleyen Mardin (1992; 8), “Türkiye'de laik konuma sahip kesimlerin en sert eleştiri yönelttikleri Bediüzzaman Said Nursi üzerine araştırma yapma cesaretinin” karşılığını Türkiye Bilimler Akademisi (TÜBA) üyeliğinden atılmakla alacaktır. Bilimin otoriter bir rejimin ideolojisi olarak yapılandırılması sonucunda fikir ve düşünce hürriyeti maalesef akademik camiada bir engizisyon sisteminin kurulmasını netice vermiştir.

Mardin (1992; 34-35), Türk resmi akademik camiasından kovulsa da State University of New York Press'te yayımladığı eserinde Bediüzzaman Said Nursi'nin ana hedefini "Batı

hayata geçildiğinde dini hak ve hürriyetler genişledi. Bediüzzaman, bu dönemde eserlerini matbaalarda bastırdı. Said Nursi, 23 Mart 1960'ta Urfa'da vefat etti (Yeni Türk Ansiklopedisi, 1985; 3345-3351).

${ }^{3} \mathrm{Bu}$ konularda ayrıntılı bilgi için bkz; Bekir Berk, Hakkın Zaferi İçin, İstanbul: Yeni Asya, 1972; Bekir Berk, Nurculuk Davası, İstanbul: Yeni Asya, 1975; Sabahaddin Aksakal, Hakkın Müdafaası, İstanbul: Yeni Asya, 1973. 
materyalizm ve maddeciliğinin İslam'a sızmasını önlemek" olarak tesbit ettikten sonra (1992; 20), Onu "zamanımızda Müslümanlar için uygun düşen tavrın ilkelerini Kur'an'dan çıkaran bir İslam bilimleri uzmanı” olarak tanımlar ve İslamî cemaatin yeniden canlandırılmasında tuttuğu yolun önemine dikkati çeker.

Mısır'da İhvanı Müslimîn ve Pakistan'da Cemati İslamî, siyasî yapılanmalar şeklinde tavandan tabana yani devletten ferde uzanan bir yapılanma biçimini esas alırken; Said Nursi tabandan tavana, yani fertten cemiyete ve devlete doğru tedrici bir yapılanmayı tercih etmiştir. Önce kafalarda ve kalplerde sahih bir imanın yerleşmesinin vazgeçilmezliği üzerinde durarak daha sonra halkaları hayatı içtimaiye ve siyasîyeye doğru uzatmıştır. Risale-i Nur Külliyatı olarak bilinen ve 130 parçadan oluşan eserlerinde Kur'an'ın mesajını tam da materyalistlerin en büyük silahı olan tabiatı onların ellerinden alarak vermekte; çiçekleri, böcekleri ve diğer varlıkları Allah'ı tanıtan âyetler olarak takdim etmekte ve öğrencilere de "öğretmenleri Allah'tan bahsetmese de" okudukları her bir fennin Allah'1 tanıttığını, bu sebeple öğretmenleri değil fenleri dinlemelerini tavsiye etmektedir (Mardin, 1992; 34-35).

Said Nursi'nin bir tecdit hareketine giriştiğini, çağımızda iletişimin önemini en önce kavrayarak Kur'an'ın mesajlarını topluma açık iletişim sistemini kullanarak verdiği, mesela radyoyu "milyonlar dilli bir hâfızı Kur'an" olarak Allah'ın bir nimeti şeklinde tanımladığı, hizmet metodu olarak da ananevi tarikatlardaki dikey bir yapılanma olan şeyh, halife, mürid geleneği yerine hiyerarşik olmayan yatay bir yapılanma (kardeşlik) ve şeyh yerine de mesajı koymasını çağımıza özgü sosyolojik bir gerçeklik olarak ifade eden Mardin ${ }^{4}$, tarikatlara ve geleneksel İslam anlaşıyına karşı olan Kemalist cumhuriyetin, Bediüzzaman'a karşı olma sebebini de Kemalizmin pozitivist felsefi temelini oluşturan materyalizme saldırması olarak açıklar (Mardin, 1992; 62-69).

Şerif Mardin'e Bediüzzaman'1 incelemesini tavsiye eden Meriç'e göre (1978; 211), Said Nursi'nin inkılâptan anladığı cumhuriyeti kuran kadrolardan farklıydı. Mustafa Kemal ve arkadaşlarının inkılâptan anladığı şey düpedüz ihtilâlken, Said Nursi davet edildiği TBMM'de yapılacağı söylenen inkılâpların memleket şartlarına yani İslamî esaslara uygun olmasını istiyor ve inkılâpların serbest iradeye dayalı olarak gerçekleştirilmesini savunuyordu. O'na göre cebir yoluyla hiçbir fikir ve tarzı hayat halk önünde muteber olamazdı. Efkâr-1 ammeye kendini sevdirmek ve medeniyet âlemine katılmak, ihtilal ve fesadı ortadan kaldıracak bir devlet tesis etmek ancak böyle mümkün olabilirdi. Oysa inkılâbı yapanlar İslamîyeti diriltmek değil, İslamîyete rağmen laik ve Avrupaî bir devlet kurmak istiyorlardı. Cumhuriyetin Adalet

\footnotetext{
4 Bazı dini kimlikli cemaatlerin Nur harketi'nin bir parçasıymış gibi algılanması veya algılatılması gerçekçi değildir. Mesela kendisini "Hizmet Hareketi" olarak tanımlayan fakat Devletin resmi belgelerinde "Paralel Devlet Yapılanması" (PDY) veya Fetullahçı Terör Örgütü (FETÖ) olarak tanımlanan yapının ne kullandığı metot, ne de yapı ve işleyiş olarak Nur hareketi ile bir ilişik ve benzerliği bulunmamaktadır.
} 
Bakanı genç hukukçulara "Ellerinizdeki inkılâp oklarını irticaın kalbine saplayınız." diye sesleniyordu (Mürsel, 1976; 327). Bediüzzaman Ankara’nın niyetini anlamıştı.

Said Nursi'nin siyasete ilişkin hareket tarzı hakkındaki tespitlerinde Mardin (1992: 153-164), Bediüzzaman'nın TBMM'nin daveti üzerine 1922 yazında Ankara'ya yaptığ ziyarette gördügü siyasî yapıyı iyi analiz ettiğini ve siyasî muhalefetin netice vermeyeceğine kanaat getirdikten sonra daha etkili ve legal bir muhalefet tarzı olan iman hakikatlerini yayarak, şiddetten uzak imanî bir cereyanına kuvvet verdiğini, tek parti rejimin çökmesi ve çok partili hayata geçilmesi ile birlikte de Demokrat Parti'ye açık destek vererek hürriyet ve demokrasiden yana olan tutumunu ortaya koyduğunu ve İslam dünyası için temennisinin de üç temel görevden üçüncüsü olan İslam birliğinin hilâfetin şahsı mânevisi altında sağlanması olduğunu ifade etmektedir.

Said Nursi'nin cumhuriyet dönemindeki kelle hasadı yapan İstiklal Mahkemelerinden ve keyfi tasarruflardan hayatını nasıl koruduğu hep bir sual olarak kafalarda yerini korumuştur. İhvanı Müslimîn'nin kurcusu Hasan el Benna ve ideologu Seyyit Kutub'a benzer bir akıbetin Bediüzzaman'da görülmemesi şüphesiz takdiri İlâhidir. Beşeri tarafında ise birincisi, otoriter rejim taraftarlarının O'nu her vakit tarassut altında tutarak hin-i hacette O’nun üzerinden büyük bir operasyon yapma arzusu olmalıdır. İkincisi ise Bediüzzaman'ın sıradan bir âlim olmadığı, 10 Temmuz 1908'de Selanik Hürriyet Meydanı'nda hürriyeti takdir eden ilk nutku söylediği (Kutay, 1980; 111), Birinci Dünya Harbinde doğu cephesinde görevli olan Mustafa Kemal'in, gönüllü alay kumandanı olarak Bitlis'i kurtarmada Said Nursi'nin yaptığı kahramanlığ 1 yakinen bildiği, burada Ruslara esir düşen Bediüzzaman'ın 1917 yılı baharında esaretten kurtularak İstanbul'a geldiği ve o dönemde Hilâfetin en yüksek müessesesi olan Dar-ul Hikmeti'l-İslamîye üyeliğine seçilerek İngiliz işgaline karşı mücadele ettiği ve İngiliz baskısı ile çıkarılan fetvaya karşı çıkıp, milli mücadele lehinde fetva verdiği gibi hususlar ile özellikle Şeyh Said isyanındaki tavrı Ankara tarafından bilinmekte idi (Mardin, 1992; 135).

Tüm bunlara rağmen doğal bir ölüm süsü verilmek istenen suikastlar da hiç eksik olmamıştır. Tarihçe-i Hayatında kendisinin 18 kere zehirlendiğini ifade ettiğini ve bunlardan bazılarının suyuna ve yemeğine zehir katma şeklinde, bazılarının ise hapishanede hastalıklara karşı aşı yapma bahanesi ile olduğunu belirterek, iğnenin yapıldığ 1 yerde toplanıp kuruyan ve vücudunda çukur oluşturan parçaları talebelerine gösterdiği nakledilmektedir (Nursi, 1962; 418).

Bediüzzaman hayatı boyunca çektiği en ağır işkencelere rağmen ülke içinde birinci tavsiyesi "asayişi ihlâl etmemek, bilakis her kalp ve kafaya imanla mânevi bir yasakçı koyarak ülkede huzur ve sükûna destek vermek" olmuştur. Kutay (1980; 436), CHP'nin 
Dâhiliye Vekili Hilmi Uran'ın Köşkteki bir toplantıda Reis-i Cumhur İsmet İnönü’ye bilgi verirken "mahkemelerin Said Nursi'yi bir türlü mahkûm edemediğinden" söz etmesi üzerine İnönü'nün; “Zeki adamdır. Divan-1 Harpler ve İstiklâl Mahkemelerinden yakasını kurtarmasını bildi." dediğini nakletmektedir. Bu hâtıra bile Nursi'nin kanun ve nizama riayetteki dikkatini ve tahriklerle asayişi ihlâl üzerinden operasyon kurgularına fırsat vermediğini ortaya koymaktadır.

\section{3. İhvanı Müslimîn ve Hasan el Benna}

İhvan adında ilk hareket Arabistan'da ortaya çıkmıştır. Suûd bin Abdülaziz tarafından göçebe unsurları yerleşik hayata geçirmek için 1912 yılında Hujar (Hicra) denilen alanlara iskân edilen bedeviler İhvan'ın temelini oluşturmuştur. İhvan Teşkilatı, Suûdî Arabistan'ın kuruluş sürecinde Vahhabîlik anlayışı benimsetilmiş bedevi Araplardan müteşekkil askeri birliklerdir. Suûdî yönetimi bu süreçte İhvandan hem askeri hem de ideolojik olarak destek almıştır. Abdülaziz yönetimi, merkezi devlet olma aşamasında hem askeri hem de ideolojik özelliklerinden yararlandığı İhvan örgütlenmesini, modernleşme ve farklı mezhepleri tek bir yönetim altında birleştirme noktasına gelindiğinde, bu politikalarının önünde bir engel olarak görmüş ve tasfiye etmek istemiştir. Vahhabî inancına aşırı bir sadakati söz konusu olan İhvan, Suûdî Devleti'nin kurulmasından sonra Suud Ailesinin Batılı ülkelerle işbirliği içine girmeleri üzerine isyan etmiş ve isyanları yönetim tarafından bastırılmıştır (Ataman ve Kuşcu, 2012; 78: Ünlüsoy, 2016: 39-75).

Mısır'daki İhvanı Müslimîn ise Hasan el-Benna ${ }^{5}$ tarafından 1928 yılında Mısır'ın İsmailiye şehrinde kurulmuştur. İlk üç yıl faaliyetlerini yalnız lise öğrencileri ve işçiler üzerinden sürdüren hareket daha sonra Hasan el Benna'nın karizmatik kişiliği ve grup üyeliğinin işçiler ve öğrenciler arasında bir organizasyona dönüşmesi, hareketin diğer kasabalara da yayılmasını sağlamıştır. 1932'de Müslüman Kardeşler faaliyetlerini daha geniş bölgelere yaymak için merkez olarak kendine Kahire’yi seçmiş, Kahire'de Hasan el Benna'nın konferansları, halk buluşmaları, seyahatleri bir grup hareketinden bir

\footnotetext{
${ }^{5}$ Hasan b. Ahmed b. Abdurrahman el-Bennâ 14 Ekim 1906 yılında İskenderiye'de doğdu. 1923'te Kahire'de dini ve içtimai konularda eğitim veren Darü'I-Ulûm adlı öğretmen okuluna kaydoldu. 1927'de Arapça öğretmeni olarak Süveyş Kanalı yakınlarında bulunan İsmailiye'de bir ilkokula atandı. Mart 1928'de bir İngiliz kampında çalışan altı kişiyle birlikte İslamın ilkelerine geri dönüşü amaçlayan Müslüman Kardeşler'i kurdu. 2. Dünya Savaşı başladığında çok sayıda öğrenci, devlet memuru ve işçi Müslüman Kardeşler'e üyeydi ve Örgüt Mısır toplumunun hemen bütün kesimlerini temsil eden önemli bir siyasi güç olmuştu. Örgüt üyelerinin birçoğu hükümetin ulusal çıkarlara ihanet ettiği görüşündeydi; Hasan el-Benna ise bir süre daha hükümeti destekleme taktiğine bağı kalmaya çalıştı. Savaşı izleyen kargaşa ortamında el-Benna'nın sözünü geçiremediği örgüt üyelerinin adları, başta Başbakan en-Nukraşi'nin öldürülmesi olmak üzere (Aralık 1948), bir dizi suikast olayına karıştı. Hasan el-Benna Şubat 1949 'da hükümetin göz yumduğu bir suikast sonucunda Kahire'de öldürüldü (Ganim, 1997: 307).
} 
organizasyona dönüşmesini sağlamıştır. Önce hareket kendisini Benna'nın kardeşleri olarak isimlendirmiş, daha sonra da İhvan-ı Müslimin adını almıştır (Tı̆̆lı, 2011; 39).

Hasan el Benna, reformizm ve entellektüalizm girdabindaki Muhammed Abduh ve Reşit Rıza gibi isimlerin Avrupaî tesirlerinden kaçınmaya çalışmıştır. Müslümanlardaki ahlâki bozulma ile siyasî, ekonomik ve kültürel olarak egemen yabancılara bağımlılık onu derinden etkilenmiş, Müslüman Kardeşler'i, kalplerin ve beyinlerin eğitimine ve düzeltilmesine dönük bir hareket olarak başlatmıştır. Hareket kısa sürede büyümüş ve ülkenin birçok kesimine yayılmıştır. İhvanın mesajı esas olarak İslamî düzenin kurulması ile ilgili olmakla birlikte, İslam Devleti bu düzende ana unsurdur. $\mathrm{Bu}$ durum ileride geliştirilecek ve Müslüman Kardeşler' in bugüne kadar gelen sloganı olacak şu sözde açıkça ortaya konmuştur; "Gayemiz Allah, yasamız Kur'an, önderimiz Peygamber'dir; yolumuz mücadeledir; Allah uğruna ölmek en yüksek arzumuzdur". Hareketin erken siyasîleşmesi bu amacı erdemli bir cemaat ve İslamî siyasî düzen bağlamının içine yerleştirmiştir; İslamî davranışları ve ibadet vazifelerini yerine getirmeyi mümkün kılacak imkân ve koşulların sağlanmasını ve desteklenmesini gerektiren davranış ya da eylem içeren yükümlülük gerektirir. Toplumsal adaletin Kur'an'da belirlendiği şekliyle idamesini gerektirir. Marksizm ve materyalizmi kınamışlar, kapitalizmi riba'ya (tefecilik) dayalı bir sistem olarak görmüşlerdir (İnayet, 2008: 149).

Müslüman Kardeşler, 1949'a gelindiğinde ülkenin en büyük sosyal organizasyonu durumuna gelmiş, hatta Hür Subaylar darbesini yapanlardan Cemal Abdünnasır bile bir süre hareketin içerisinde aktif çalışmalarda bulunmuştur. İkinci Dünya Harbi'nin sona ermesiyle Misır yönetimi tekrar hareket üzerine gitmeye başlayarak Kahire'nin dış mahallerinde yeni şehre gelmiş sakinlerine karşı operasyon başlatmıştır. Yüzlerce İhvan mensubu tutuklanarak hapse atılmış, Mısır Başbakanı Mahmud Fahmi Nukraşi’ye suikast düzenledikleri gerekçesiyle örgütün üst düzey yöneticilerin hepsi tutuklanarak bir kısmı hakkında idam cezası verilmiş ve cezalar infaz edilmiştir.

Müslüman Kardeşler'in dini ve siyasî ideolojisi esas olarak Hasan el Benna ve Seyyid Kutup tarafından geliştirilmiştir. Etkisinin geniş bir coğrafyaya yayılmasında rol oynayan başlıca unsur örgütün, İslam dünyasının siyasal ve kültürel olarak ciddi bir kaosun içinde bulunduğu bir dönemde kurulmasından ve İslamî bir yönetimi alternatif olarak sunmasından kaynaklanmıştır. Müslüman Kardeşler'in kurucusu olan Hasan Benna'nın esas üç temel öğretisi "dini eğitim, uyanış ve örgütlülük" olarak ifade edilmektedir. Benna, bir İslamî devletin kurulması sürecinde önceliğin, askeri mücadeleden ziyade toplumsal yapının İslamîyet bilinci çerçevesinde yeniden yapılandırılmasını öngörmektedir. Toplumun eğitim ve örgütlenme ile kültürel ve bilinç düzeyinde dönüşümünün sağlanmasının ardından İslam Devletinin kurulabileceğini öngörmektedir (Ayhan, 2009; 108-109). 
Hasan el Benna'nın ölümünden sonra hareketin liderliğine getirilen Hasan Hüdeybi, Müslüman Kardeşleri daha geleneksel ve esnek bir çizgiye çekerken Seyyid Kutub'un başını çektiği muhalif kanat entelektüel ve politik amaçların öne çıkarılmasında ısrarcı olmuştur. Misır'da 1938'den sonra siyasî nitelik kazanmaya başlayan İhvan 1940'ların sonunda Mısır'daki monarşi ve iktidardaki Vafd Partisi'ne karşı tehdit oluşturduğu için 1952'deki Hür Subaylar Darbesi'nden sonra tüm partiler ile beraber kapatılmıştır. 1954'te Cemal Abdülnasır'a yönelik suikast girişiminden sonra, altı lideri vatana ihanet suçundan idam edilmiş ve hareket şiddet yoluyla bastırılmıştır. 1980'lerden itibaren tekrar canlanma dönemine giren Müslüman Kardeşler Örgütü'nün şiddet yanlısı uzantıları Hüsnü Mübarek yönetimince sert bir şekilde bastırılmıştır.

Geçmişte bazı mensuplarının şiddet eylemlerine karıştığını kabul eden hareket önderleri artık şiddete dayalı taktiklerin tamamen terk edildiğini ve şiddetin hâlihazırdaki İhvan örgütü tarafından bir yöntem olarak reddedildiğini ifade etmiştir. Hatta günümüzde hareket şiddetin tümüyle terk edildiği şeklindeki söylemi özellikle ve sıklıkla kullanmaktadır. Şiddetsizliğe özel bir önem atfeden İhvan, özellikle Batıda hareket ile ilgili var olan genel kabulleri yıkmak için böyle bir stratejiyi benimsemiştir (Çakmak, 2007; 86).

Müslüman Kardeşler 1990'lı yıllarda söylem ve tarzlarında demokrasi ve liberal eğilimlere yönelmiş, şiddet ve çatışma unsurlarını bir kenara bırakarak devletle birlikte var olma anlayışını benimsemiştir. Hareketin bu yıllardaki faaliyetleri dikkatli incelendiğinde kamuoyuna yapılan açıklamaların siyasî eleştiriden uzaklaşmaya başladığı görülür. Bu siyaset değişikliğinin sebebi ise o yıllarda Mısır'da ortaya çıkan şiddet eğilimli cihat hareketlerinden kendilerini koruma düşüncesidir (Tığlı, 2011; 43).

Arap Baharıyla birlikte İhvan-1 Müslimîn milli iradenin tecellisine razı olmuş ve nitekim yapılan demokratik seçimler İhvan hareketini kısa süreliğine de olsa iktidara taşımıştır. Ancak bu sefer de ABD ve Batılı ülkeler Arap Baharı ile gelen demokratikleşmeden ürkerek süreci tersine çevirmeye başlamış ve tavrın ilk tezahürü de yine Mısır'da seçilmiş cumhurbaşkanı Muhammed Mursi'nin bir askeri darbe ile indirilmesi, yerine de darbe yapan generalin oturtulması ile sona ermiştir.

\section{Nur Hareketi İle İhvanı Müslimînin Demokrasiye Bakışı}

Demokrasi, Yunan menşeli bir kelime olup halkın yönetimi manasına gelmektedir. Demokrasi üzerine yapılmış tüm tarif ve tanımlamalarda halk iradesi esas alınmaktadır. Türk Demokrasi Vakfi'nca yayımlanan bir kitapçıkta (1992; 9) demokrasi “Üstün iktidarın halkta bulunduğu veya halk tarafından doğrudan ya da özgür bir seçim sistemi içinde seçilmiş temsilcileri aracılığıyla kullanıldığı, halk tarafından yönetimin adı" şeklinde tarif edilmiştir. 
Acaba İslam dininde demokrasi kendine yer bulabilmiş midir veya nasıl bir yer bulabilmiştir? Bu soruların cevabından önce İslam'da devlet idaresi için çizilmiş bir çerçeve ve metinlerde bir şablon olup olmadığına bakmak gerekmektedir. Bu konularla ilgili ifratçı, tefritçi ve vasat olan görüşler bulunmaktadır. İfratçı görüşler İslam'ın yönetim anlayışının tam da demokrasi olduğu yönünde iken, tefritçi görüşlerde İslam'in demokrasi ile uzaktan yakından bir ilişkisi yoktur. Vasat yolu takip edenler ise kelime üstünden konuya yaklaşmak yerine demokrasinin tanımı üzerinden meseleyi analiz etmekte ve İslam'1n temelde demokrasi ile çelişmediğini ifade etmektedirler.

Said Nursi'nin cumhuriyet ve demokrasi konusundaki fikirleri, Nur hareketinin anlaşılmasında yeterli ipuçları vermektedir. Eskişehir Mahkemesinde hâkimin cumhuriyet hakkında fikrini sorması üzerine O, "Yaşlı mahkeme reisinden başka orada bulunanların daha dünyaya gelmeden önce kendisinin dindar bir cumhuriyetçi olduğunu" eserlerinden Tarihçe-i Hayat'1 delil göstererek cevaplamıştır. Dini cenahtan gelen tenkitleri ise dört halifenin seçimle gelen halife ve reis-i cumhurlar olduğunu ifade ederek, onları "hakikat-i adaleti ve hürriyet-i şer'iyeyi taşıyan mâna-yı dindar cumhuriyetin reisleri” olarak tanımlar (Nursi, 1994; 357). 1909 yılında Dinî Ceride'de yazdığı bir makalede ise cumhuriyeti; "adalet, meşveret ve kanunda inhisarı kuvvetten ibaret” bir yönetim tarzı olarak tarif eder (Nursi, 1960; 49).

Said Nursi İstibdadı "tahakküm, muâmele-i keyfiye, tek kişi iradesi ve zor kullanma" olarak tarif etmiş, istibdadın sû-i istimâlâta gâyet müsâit bir zemin olduğunu, zulmün temeli ve insâniyetin mâhisi (yıkıcı)" olduğunu söylemiştir. Meşrutiyeti ise "hâkimiyet-i millet" olarak tarif etmiş "Ve işlerde onlarla istişare et." (Âl-i İmran Sûresi/159), "Onların aralarındaki işleri istişare iledir" (Şûra Sûresi/38) âyetlerinin tecellîsi olduğunu söylemiştir (1991; 22-23). Bediüzzaman (1991; 55-57), hürriyetin "âdâb-1 şeriatla müteeddibe ve mütezeyyine olmasını" ister. Yoksa sefahet ve rezaletteki hürriyetin nefs-i emmâreye esir olmaktan öte anlamı yoktur. O'nun tarifiyle hürriyetin gereği odur ki; “insanın ne nefsine, ne başkasına zararı dokunmasın, kanun$\mathrm{u}$ adalet ve tedipten başka hiç kimse kimseye tahakküm etmesin, herkesin hukuku mahfuz kalsın, herkes harekât-1 meşruasında şâhâne serbest olsun."

Said Nursi 1911 yllında gittiği Şam'da Emevi Camiinde verdiği bir hutbede Avrupalıların ilerlemesine ve bizim geri kalmamıza sebep olan altı tane hastalıktan bahseder. Bunlar; "ümitsizliğin içimizde hayat bulup dirilmesi, doğruluğun hayat-1 içtimaiye-i siyasîyede ölmesi, düşmanlığa muhabbet, ehl-i imanı birbirine bağlayan nuranî bağları bilmemek, istibdat ve insanların tüm gayretlerini şahsi menfaatleri için harcamalarıdır.” $\mathrm{Bu}$ hastalıkların tedavisi ise; ümitvar olmak, doğruluk, diğergamlık, muhabbet ve sevgi ile 
İslam'ın kardeşlik prensibini esas almak, devlet idaresinin şûra ve meşvereti esas alarak demokratikleşmesiyle mümkün olabilir (Nursi, 1960; 17).

Said Nursi 1919 yılında yazdığı "Rüyada Bir Hitabe" isimli makalesinde Batı medeniyetinin dayandığı felsefi temeller sebebiyle insanlığı mutlu edemeyeceğini, gelir dağılımı adaletsizliği, sömürü ve zorbalığı netice vereceğini belirtmiş, onun eksiklerini ve kusurlarını ancak İslâm medeniyetinin esaslarının düzeltebileceğini ifade etmiştir (2006; 3941). Said Nursi ülkede sosyal hayatın âhengini, asayişin ihlâl edilmemesini savunarak ferdi odağına alan ve onu inançla takviye eden bir hareketin cemiyeti ve devleti kucaklayarak genişleyeceği, sonunda İslam ülkeleri ile ortak bir politikada buluşarak İslam birliği ve medeniyetini kurabileceği bir hareket tarzını esas almıştır. Siyaset ve yönetim araçlarını ele geçirerek tepeden inme metotlarla insanların davranışlarını değiştirmeye yönelik ihtilalci hareketleri tasvip etmemiştir.

İhvan-1 Müslimîn hareketi ise başlangıçta aynı hedeflere yönelmiş olmakla birlikte, daha sonra siyaseti kullanarak devlet iktidarı yoluyla hedeflerine ulaşmayı, yani tavandan tabana bir hareket tarzını tercih etmiştir. Bu tarzı hareket başta Hasan el Benna olmak üzere İhvan'ın önemli fikir ve hareket kadrolarının öldürülmesini netice vermiştir. İhvan hareketinin demokrasiye bakışı elbetteki Batılı anlamda değildir ama temel hak ve hürriyetlerin korunması, devlet idaresinde şûranın varlığı, meşru iktidar kaynağının halk olması, yöneticilerin halka karşı sorumlu olması, devlet otoritelerinin sınırlarının kanunla belirlenmesi gibi hususların da İslam'a muhalif olmadığının altı çizilmektedir. Bu açıdan bakıldığında İhvan hareketi İslam'da iktidarın kaynağının cümhur olduğu düşüncesi, Batıda da aynı mânaya gelen demokrasi ile aykırılık taşımamaktadır. ${ }^{6}$ Ayrıca hürriyetlerin İslam hukuk sistemi çerçevesinde değerlendirilmesi, İslam'da haram olarak sayılan alkol, zina, faiz vb. eylemlerin engellenmesi gerektiği ifade edilmektedir (Dalar, 2010: 54-55).

Bugün gelinen noktada Arap ülkelerinde yaşanan dönüşüm, otoriter rejimleri değiştirmede demokratik araçları kullanmanın önemini geç de olsa ortaya koymuş fakat bu sefer de karşılarına zâhirde demokrasi havarisi görünen, gerçekte ise İslam ülkelerinde diktatörlükleri destekleyen ABD ve Batılı ülkeler çıkmıştır.

\section{Nur Hareketi İle İhvanı Müslimîn'in Hizmet Metotları}


Günümüzde İslam dünyası'nın yol ayrımına geldiği konuların başında hizmet metotları gelmektedir. Gerek ülke dâhilinde ve Müslümanlar arasında, gerekse uluslararası camiada ve gayrı Müslim unsurlara ve devletlere karşı hatt-1 hareketin belirlenmesinde nasıl davranılacağı, hangi metotların takip edileceği meselesi hayati önem taşımaktadır. $\mathrm{Bu}$ hususlarda yapılacak hataların bedeli çok ağır olabilir. Bu hususta Nur Hareketi ile İhvan-1 Müslimin arasında da farklılıklar olduğu görülmektedir. Bu iki hareketin dişında olan ve ehl-i sünnet itikadına muhalif olarak ortaya çıkan Hârici ve Bâtıni mezhep ve akımlar ise bir ucu uluslararası güç odaklarının istismar ve kullanımına açık olan başka bir yapılanmayı ifade etmekte olup bu makalenin konusu dışında kalmaktadır. Ancak Mâturidi ve Eş'ari mezheplerinin teşkil ettiği Sünni İslam'ı Şia ve Vahhabî kutuplaşması üzerinden zayıflatmak ve aynı zamanda İslam'ı tedhiş ve terörle lekelendirmek isteyen güç odaklarının IŞİD/DEAŞ ve Hizbullah gibi hârici ve bâtıni hareketleri sahaya sürdüğü ve onlar üzerinden amaçlarına ulaşmaya çalıştığını ifade etmek gerekir.

\subsection{Nur Hareketi'nin Hizmet Metotları}

Türkiye'de Nur hareketi 1950 yılına kadar siyasî bir yapılanma, dernek veya vakıf şeklinde bir hükmi şahsiyet kurma gibi yollardan hiçbirisine tevessül etmediği gibi, bu dönem içerisinde siyasî cereyanlara tarafgirlik şeklinde bir eğilimi bile hoş görmemiştir. Türkiye'deki otoriter tek parti yönetiminin her türlü muhalefeti boğduğu, hatta sun'i muhalefetler icad edip daha sonra onlar üzerinden imha operasyonları yaptığı bir dönemde belki de en akıllı muhalefet tarsi, siyasete hiçbir şekilde iltifat etmemekti. Bu sebeple Nur hareketi bu alanı tarafgirlik seviyesinde bile terk ederek nisbeten daha az göze batan eğitim yoluyla ferden ferda iman ve itikat noktasında kişileri takviye etme yolunu seçmiştir.

Fen ve felsefeyi kullanarak maarif üzerinden yaygınlık kazanmaya çalışan materyalizm, ateizm, marksizm gibi cereyanların özellikle genç nesiller üzerindeki tahribatına karşı koyma, İslamî eğitimin ortadan kaldırılmasıyla toplumda ortaya çıkan inanç zaafını giderme ve dini bilgilere muhtaç olan insanlara, İslam'1 akla ve mantığa uygun olarak anlatma şeklinde özetlenebilecek bu hareket tarzı, o günkü otoriter yapının dikkatini çekmeye başladığında ise zaten gerekli altyapıyı kurmayı başarmıştı. Ayrıca nisbeten kasaba ve köylerde elle yazılmış dini muhtevalı risalelerin mevcut siyasî yapıyı tehdit edeceğine ihtimal verilemezdi. Olay sadece kontrol altında tutulan Diyanet camiası dışında, üstelik yasaklanan Osmanlıca alfabe kullanılarak eser telif edilmesiydi. Buna rağmen konu mahkemelere intikal ettirilmiş, istihbarat ve emniyet güçleri Said Nursi ve onun eserlerini okuyanları yakın takibe almıştır. Hazırlanan bilirkişi raporları Nur risalelerinde siyasî muhteva ve muhalefet bulunmadığını, iman ve itikat gibi konuların işlendiğini belirtmişlerse de Said Nursi tutukluluk ve gözaltında tutma şeklinde bir takibattan vefatına kadar kurtulamamıştır. 
Said Nursî’nin fikrî ve içtimaî hayatı ve mücadelesi, İslâm Dünyasının bu asır içinde geçirdiği değişik safhaların bir model şahsın hayatına aksetmiş hali gibidir. O kendisi ile ilgili üç Said tanımlaması yapmaktadır. Bunlardan Eski Said dediği dönemde siyaseti ve siyasetin araçlarını kullanarak İslam'a ve İslam birliğine hizmet etmek istediğini ifade etmektedir. Cumhuriyete geçişe kadar olan dönemde ülke ve dünya siyasetini yakından takip eden, gazetelerde makaleler neşreden, sivil toplum hareketi içinde kuvvetli şsekilde var olan, ülkedeki eğitim sisteminin yeniden yapılandırılması, hatta İslam Birliği'nin alt yapısını oluşturacak üç dille tedrisatın yapılacağı bir üniversite için Padişaha müracaat eden, ilmî münazaralar kadar meydan nutuklarıyla fikirlerini ifade eden ve ağırlıklı olarak da İslam'ın doğru anlaşılması için eserler telif eden bir Said Nursi vardır.

Cumhuriyetin ilanı sürecinde ise Eski Said vazifesini Yeni Said'e devretmiştir. Yeni Said'in tek gündemi vardır. İmha edilmek istenen, esasları tahrif edilmeye çalışılan İslam'ın iman esaslarını “asrın idrakine” göre yeniden anlatmak. Artık O’nun gündeminde ne cemiyet, ne siyaset, ne gazete ve radyo ve ne de uluslararası hâdiseler vardır. Muhalefetin yok edildiği bir dönemde kendisini iman davasına adayarak belki de en büyük muhalefeti gerçekleştirmiştir. Bediüzzaman'ın Eski Said ile Yeni Said dönemleri arasında yaptığı ayrım aynı zamanda İslâm dünyasının birinci dönemi ile ikinci dönemi arasındaki ayrımı yansıtmaktadır. Birinci dönemde Eski Said olarak İslâm âleminin ihtiyaç hissettiği siyasî reformlar için aktif siyaset içinde yer alan Bediüzzaman, ikinci dönemde Yeni Said olarak tam bir siyasî fetret dönemine girmiş olan İ́lâm âleminin siyasî yapısını yeniden kurmaktan çok bir İslâm bireyinin imanını yeniden inşa ederek bu bireyden bir İslâm cemaati çıkarmak gayreti içine girmiştir. Felsefe temelli ideolojilerin siyasî sistem üzerindeki etkilerinin arttı̆̆ bir dönemde Bediüzzaman'ın fertlerin imanını kurtarmak konusuna verdiği önem, temel çözümü müessesevî yenilenmelerden çok bireyin imanının müdafaası yoluyla her Müslümanı ideolojik-temelli Batı yayılmacılığına karşı bir direniş odağı haline getirmekte gördüğünü ortaya koymaktadır. Bu tesbit ve tavır da İslâm âleminin o dönemki genel durumu ile uyum içindedir (Davutoğlu, 1995; 10-11).

Bediüzzaman'ın az bilinen ve kendisini "Üçüncü Said” olarak nitelediği bir dönem daha vardır. Bu dönem Türkiye'de totaliter rejimin beyaz ihtilal denilen halk hareketi ile yıkıldığı ve Demokrat Parti'nin seçimle iktidara geldiği 1950'li yılları ifade eder. Bu dönem Bediüzzaman'ın siyasî hareketleri analiz ettiği; Cumhurbaşkanına, Başbakan Adnan Menderes'e ve sair siyasî şahsiyet ve bakanlara mektuplar yazdığı, tavsiyelerde bulunduğu, İslam birliği için onlara sorumluluklarını hatırlattığı, özellikle Müslümanlara metot tavsiyesinde bulunduğu bir dönemdir. Bazı örnekler üzerinden Müslümanların ülke dâhilinde asla şiddete tevessül edemeyeceği, asayişi ihlal etmenin bir iç kanama olacağı, meselenin fert bazında imanı takviye ve tahkimle, tabandan tavana bir yol takip etmesi şeklindedir. Cihat 
ancak hârici düşmanın tecavüzüne karşı yapılır, dâhilde cihat ise eğitim ve 1slah hareketleri şeklinde ikna metodu ile olabilir.

Bediüzzaman vefatından önce talebelerine verdiği son dersinde müsbet hareket tavsiyesinde bulunarak menfi hareketi kesinlikle menetmiş, bu hususta "âsâyişi muhafazayı netice veren müsbet iman hizmeti içinde herbir sıkıntıya karşı sabırla, şükürle mukabele edilmesini" salık vermiştir. Hâriçteki cihad ile dâhildeki cihadın farklı olduğunu, haricî tecavüze karşı kuvvetle mukabele edilirken, dâhildeki hareketin müsbet bir şekilde mânevî tahribata karşı mânevî ihlâs sırrıyla hareket etmek olduğunu, kesinlikle kuvvet kullanılamayacağını ifade etmiştir (Nursi, 1960; 241-242).

Üçüncü Said, İslâm dünyasının ittihadı ve dünya siyasetinde etkili bir güç olması için fikri ve ameli bir çaba içine girer. Bir başka açıdan bakılırsa ikinci dönemdeki sömürge kalıplarını kıran İslâm dünyası gibi Üçüncü Said de Yeni Said dönemindeki istibdat kalıplarını kırarak Yeni Said'in inşa ettiği iman temeli üzerine sosyal ve siyasî boyutlar eklemeye çalışır. Böylece Üçüncü Said ilerlemiş yaşına rağmen Eski ve Yeni Said'in tecrübe birikimlerini mezcetmiş ve bunu sosyal ilişkilerine de aksettirmiştir (Davutoğlu, 1995; 12-14).

\section{2. İhvanı Müslimîn’in Hizmet Metotları}

İhvan-1 Müslimîn, İslamî bir harekettir ve hemen hemen bütün İslamî hareketler gibi cihada özel bir önem atfetmektedir. Ancak İhvan'ın cihada bakışı ve cihad ile ilgili uygulamaları birçok İslamî hareketten oldukça farklıdır. Her şeyden önce İhvan cihada söylem düzeyinde yer vermekle kalmamış, cihadı eylemlerinin odağına koymuştur. Dahası, İhvan cihadı sadece çatışma olarak görmemiş, tebliğ ve davet gibi yumuşak, ama daha etkili metotlara da ağırlık vermiştir. Şiddeti bir cihat yöntemi olarak kullandığı durumlarda da genel itibarı ile savaş hukuku kurallarına riayet etmiş ve sivillere yönelik saldırılardan kaçınmıştır.

İhvanın şiddet içeren cihadında iki önemli hedef olagelmiştir. Bunlardan biri İngiltere'dir. İngiltere İhvan açısından emperyalizmin önde gelen aktörüdür. Benna'ya göre İhvan'ın temel hedefi önce bütün Müslüman topraklarının yabancı hâkimiyetinden kurtulması, bu topraklarda İslamî bir idarenin kurulması ve daha sonra da bir bütün olarak toplumun dönüştürülmesidir. İngilizlerin Siyonistler ile işbirliği yaptığını ve savaş sonunda Filistin'de bir Yahudi devleti kuracağını düşünen teşkilat, İngilizleri Mısır'dan çıkarmak ve Filistin'i kurtarmak amacı ile gizli bir mücahit ordusu kurmuştur.

İslamî metotları kullanmak isteyen hareketlerin en önemlisi ve kendisi dışındaki benzer hareketlerin en önemli ilham kaynağı olan İhvanı Müslimîn veya Müslüman Kardeşler Hareketi, kuruluşunun üzerinden uzunca bir süre geçmiş olmasına rağmen günümüz Ortadoğu siyasetinde hâlâ etkili bir rol oynayabilmektedir. Kaygan bir toplumsal tabana sahip olmasına 
rağmen hareket aktivist karakterini hiçbir zaman kaybetmemiş, bu da hareketi canlı tutmuştur. $\mathrm{Bu}$ sayede hareket Arap dünyasının neredeyse tek sivil hareketi olarak adından sıkça söz ettirmektedir. Sivil kitlelerin siyasî süreçlere katılımının son derece sınırlı olduğu Arap dünyasında Müslüman Kardeşler örgütü çok önemli bir rol oynamış ve sivil kitlelerin taleplerinin kısmen de olsa siyaset alanına taşınmasına katkıda bulunmuştur.

Bununla birlikte hareket gerçek bir sivil toplum örgütlenmesi örneği gösterememiş, bu da hareket ile ilgili önemli şüphelerin ortaya çıkmasına sebep olmuştur. Şiddeti metot olarak benimsememiş olmasına rağmen zaman zaman şiddeti tamamen reddettiğini açık ve kesin bir şekilde ifade edemeyen ve şiddet merkezli bir yöntem izleyen ve kendini İslamî hareket olarak gören diğer akımlar arasında belirgin bir mesafe koymada zaman zaman başarısız olan Müslüman Kardeşler, kendi tabanı dışında genelde şüphe ile karşılanmıştır. Ancak bugüne kadar terörizm sayılan eylemler ile resmi olarak İhvan üyesi arasında müşahhas bir bağlantı bulunabilmiş değildir. Buna karşılık İhvan, bazı üyelerinin radikal eylemler gerçekleştirdiğini inkâr etmemektedir. Bu nedenledir ki şiddeti yöntem olarak benimseyen radikal örgütler ile aynı amacı paylaşıyor diye İhvanın da benzer yöntemler kullanacağını iddia etmek mümkün değildir (Çakmak, 2007; 95-96).

Sovyetler Birliğinin dağılmasından sonra İslam dünyasının yeniden hedef tahtasına oturtulması ve İslam nefretine malzeme sağlamak amacıyla İslamla şiddet arasında illiyet bağı kurmaya çalışan küresel güçlerin yönlendirdiği radikal örgütler İhvan hareketini teyakkuza sevketmiştir. İslam adına terör ve şiddet uygulayan radikal örgütlerin eylemleri, İhvan hareketinin İslamın şiddet yöntemiyle değil, tebliğ ve irşad faaliyetleriyle yayılması politikasını benimsemesinde etkili olmuştur. İktidara gelmenin ancak demokrasinin araçlarından olan seçimlerle mümkün olabileceği noktasına gelen İhvanı Müslimîn demokratik kurallara uyma konusunda diğer partilerle mutabakata vararak taahhütte bulunmuştur. (Dalar, 2010: 54-55).

\subsection{Nur Hareketi ve İhvan-ı Müslimîn Arasında Bir Karşılaștırma}

1996 genel seçimleri öncesinde Mısır'dan İhvan-1 Müslimîn'in reisi Mustafa Meşhur ile beş arkadaşı Nur hareketinin önemli isimlerinden Mehmet Kırkıncı ile görüşerek Refah Partisi lehine destek talep etmesi, İhvan ile Milli Görüş arasındaki ilişkilerin derecesini göstermesi bakımından mânidardır. Mânidar olan diğer bir husus ise Nur hareketinin Milli Görüş ile farklılığında yatmaktadır. İhvan'ın Mısır lideri Meşhur'un; "Milli görüş ile fikir farklılığınız yok, fakat hedefinize giderken kullandığınız metotlarınız farklı. Siz insanları fert fert irşat etmeye çalışıyorsunuz. Fakat bunun sonu gelmez. Gayenize ulaşmak için memleketin mukadderatına fiilen hâkim olmanız lâzım, bu da siyaset ile olur. Böylece 
yolunuz kısalır. Bunu gerçekleştirmek için iki yol var. Birisi siyasî bir cereyana mensup olmak, diğeri örgütlenerek silahlanmaktır." Görüşüne karşı;

“Bu zamanda ehl-i İslâm'ın en mühim tehlikesi, fen ve felsefeden gelen bir dalaletle kalplerin bozulması ve imanın zedelenmesidir. Bunun çare-i yegânesi: Nurdur, nur göstermektir ki, kalpler 1slah olsun, imanlar kurtulsun. Eğer siyaset topuzuyla hareket edilse, galebe çalınsa, o kâfirler münâfık derecesine iner. Münâfık, kâfirden daha fenadır. Demek, topuz böyle bir zamanda kalbi ıslah etmez. Silahlanmaya gelince, Üstadımız, silahlanmanın haricî düşmana karşı olacağını, dâhildeki cihadın manevî olacağını söylüyor. Son mektubunda da müsbet hareket etmemizi vasiyet ediyor. Müsbet hareket ise vazifemizin iman hizmeti olduğunu bilmek ve bu uğurda gayret göstermektir. Siz de bilirsiniz ki, şeriatta devlete isyan edilmez. İsyan edenlere baği denilir. Kendileri ikaz edilir, dinlemezlerse öldürülürler. Demek ki, İslamîyet'te anarşi ve teröre meydan verecek harekette bulunmak yasaktır. İşte bu yüzden bu asır fikir ve nur asrıdır, kılıç ve silah asrı değildir." Dediğini nakletmektedir (Kırkıncı, 2010).

Nur hareketinde birinci daire olarak kalp, yani birey alınmakta ve inançları sağlam bireylerden bir cemiyet inşa edilmesi hedeflenmektedir. İkinci daire ise hayatı içtimaiye dairesidir. Yani sosyal hayatın tanzimi ve inançlara uygun hale getirilmesi olup, sosyal hayatın tüm alanlarında İslamî değerlerin yer bulmasını ve tanzim edici olmasını sağlamaktır. Bunun için toplumun en az yüzde yetmişinin bu kanata sahip olması gözetilmekte, zora değil, rıza ve kabule göre bir düzenleme yapılması istenilmektedir. Üçüncüsü ise siyaset-i İslamîye dairesi olup, uluslararası sahada İslam birliğinin gerçekleştirilmesi, İslam medeniyetinin kurulması ve Müslümanların dünya siyasetinde söz sahibi yapılmasıdır. Görüldügü üzere fert, ülke ve dünya şeklinde genişleyen halkaların içi eğitim, ikna ve rıza ile doldurulmak istenilirken, siyasî baskı, zor kullanma, tedhiş, terör, ülke içinde asayişi ihlal edecek en küçük bir harekete bile izin verilmemektedir.

İhvanı Müslimîn ise tavandan tabana bir yapılanma metodu takip etmektedir. Buna göre devlet gücü siyasî yoldan ele geçirilecek ve bu güç kullanılarak İslamî bir düzen kurulacaktır. Bu hareket dâhilde şiddet kullanmayı meşru görmekte, İslam ülkesini mevcut siyasî rejim sebebiyle “daru'l harp” olarak nitelediği için isyan ve ihtilali meşrulaştırmaktadır. Nitekim İhvanı Müslimîn üyeleri zaman zaman şiddeti araç olarak kullanmaktan çekinmemişlerdir.

Türkiye'deki Nur hareketinin İhvan-1 Müslimîn cemiyeti ile münasebeti ve farkları üzerine Bağdat'ta çıkan Ed-Difa Gazetesi muharriri İsa Abdülkadir tarafından yapılan bir değerlendirme iki hareket hakkında önemli ipuçları vermektedir. Abdulkadir'e göre Nur hareketi ile İhvan'ın maksatları, "Hakaik-i Kur'âniye ve imaniyeye hizmet ve ittihad-1 İslâm 
dairesinde Müslümanların saadet-i dünyeviye ve uhreviyelerine hizmet etmek" hususlarında benzer olmakla birlikte Nur hareketinin farklı olduğu önemli hususlar bulunmaktadır.

Birincisi, Nur hareketi siyasetle arasına mesafe koyuyor, siyasî bir yapılanması da yok. İhvan ise siyasî bir cemiyet ve siyasetlerinde din önemli yer işgal ediyor. İkincisi, Nur hareketi Üstadlarıyla içtima etmiyorlar, ders almak için beraber bulunmaya lüzum görmüyorlar. Belki koca bir memleket bir dershane hükmünde, Risale-i Nur kitapları onların eline geçmekle, üstad yerine onlara bir ders verir. İhvan ise, umumî merkezlerde reisleriyle görüşür, emir ve ders alır. Bu amaçla gazeteleri ve yayınları vardır. Üçüncüsü, Nur hareketi ekser bilâd-1 İslâmiyede intişar ettiği halde hükümetlerden izin alarak toplanmaya muhtaç değiller. İhvan ise, vaziyetleri itibarıyla siyasete temas etmeye ve cemiyet teşkiline ve şubeler ve merkezler açmaya muhtaç bulunduklarından, bulundukları yerlerdeki hükûmetten icazet ve ruhsat almaya muhtaçtırlar. Dördüncüsü, Nur hareketine toplumun her kesiminden iştirak olabilir, İhvan ise siyaset iktizasıyla, ziyadeleşmeye ve kemiyete ehemmiyet veriyorlar, taraftarları arıyorlar. Beşincisi, Nur hareketinde menfaat-i maddiyeye pek önem verilmiyor. Kanaat ve fedakârlık esas alınıyor. İhvan ise Nur talebeleri gibi dünyayı terk edemiyorlar. Azamî fedakârlığa kendilerini mecbur bilmiyorlar (Nursi, 1960; 138-139).

İslamî cemaatler arasında görüş farklılığı olan hususlardan birisi de "Dâru'l-İslam ve Daru'l-Harp” meselesidir. Kısaca bazı gruplar Türkiye'nin veya yaşadığı ülkenin İslam ülkesi olup olmadığı konusunda farklı görüşler ileri sürmektedir. İslam ülkesinde tüm dini vecibeler ve kurallar İslam'ın hükümlerine riayet üzerine bina olurken "Harp diyarı” yani gayrı Müslim hâkimiyetine geçen yerler için ise harp hükümleri uygulanır. Yani savaş halinde faiz alma, yalan söyleme, aldatma, esir alma, Cuma namazı kılma, nikâh, cariye ve benzeri hususlarda İslamî esaslar değil, yine İslam'a göre özel hükümler uygulanır. Kırkıncı (1985, 27-28), hem Şafi hemde Hanefi mezhebine göre Türkiye'nin daru'l-harp olmadığını mezhep imamlarının hükümlerini açıklayarak ortaya koymaktadır. Özetle Şafi mezhebine göre "Bir diyar yahut bir memleket bir defa dahi olsun Müslümanlar tarafından zapt edilmiş ise, o diyar ve o memleket artık kıyamete kadar daru'l-İslamdır. Hanefi mezhebinde ise bir daru'l-harp, ahkâm-1 İslamîyenin bazısının icrası ile daru'l-İslam'a inkılâp eder.

Nursi (1972, 213), kesinlikle Türkiye'nin daru'l-İslam olduğunu, binaenaleyh burada asayiş ihlali, fesat, isyan çıkarma, güç kullanma gibi ancak hârici muharebe ve tecavüzde devreye girecek hareketlere tevessül edilemeyeceğini, hâricin tecavüzüne karşı maddi cihat geçerli olduğu halde dâhilde manevi cihat, yani iman hizmetlerine yoğunlaşmak gerektiğini ifade etmiştir.

\section{Sonuç}


İslam tarihi incelendiğinde dâhil ve hariçteki ihtilafların hallinde farklı metotların kullanıldığı görülür. Dâhili ihtilaflar içtihat farklılığına dayalı olarak nadiren muharebe yoluyla halledilmiş fakat Avrupa'da yaşanan ve yüzyıllarca süren din savaşları asla olmamıştır. Bu sebeple İslam dünyası büyük oranda birliğini muhafaza ederek dünya siyasetinde belirleyici güç olma pozisyonunu hiç kaybetmemiştir. Ancak Osmanlı Devleti'nin yıkılmasından sonra ilk defa İslam dünyası Batılı güçlerin siyasî, iktisadi ve askeri olarak kontrolü altına girmiş ve dünya siyasetinde temsilcisiz kalmıştır. Yaklaşık bir asır sonra İslam dünyası tekrar ayağa kalkmak için mücadele vermekte, fakat küresel güç odaklarının büyük direnci ile karşılaşmaktadır. Dünyadaki petrol ve doğal gaz gibi enerji kaynaklarının üçte ikisini elinde tutan, genç insan nüfusuna sahip, dinamik ve gelişmeye arzulu devasa bir potansiyel barındıran İslam ülkeleri karşısında; yaşlanan, yorgun, enerji kaynakları başta olmak üzere hammadde kaynaklarında büyük oranda dışa bağımlı, tek üstünlüğünü teknolojik gelişmişlik ve silah gücüne indirgemiş olan Bat1, bütün bu menfiliklerine rağmen hükümranlığını devam ettirmek arzusundadır. Bunun yolunu da İslam dünyasında iç ihtilaf çıkarmak, bunları derinleştirmek ve bunun üzerinden kendisine karşı kullanılacak enerjiyi sıfırlamanın yollarını aramaktadır. Ancak şu bilinmelidir ki İslam adını kullanarak her ne sebeple olursa olsun adam öldürmek katillik, intihar bombacılı̆̆ veya muhtelif yollarla şehirleri bombalamak fesat, ecnebi plânlarına âlet olmak ise ihanettir.

Şimdi İslam dünyasında en âcil hareket, dâhilde niza ve ihtilafları sulh yoluyla halletmek ve askeri gücü de sadece hâricin saldırılarına karşı kullanmak şeklinde olmalıdır. Bunun için Batı politikalarının tersi bir metot kullanma zarureti vardır. $\mathrm{Bu}$ hususta Bediüzzaman Said Nursi fertler düzeyinde kardeşlik, Müslüman ülkeler arasında ittihat, hârice karşı da "dostlarla mürüvvetkârane muaşeret, düşmanlarla sulhkârane muamele" şeklinde hulasa edilecek bir hareket tarzını tavsiye etmektedir. 


\section{Kaynakça}

Aksakal, S. (1973). Hakkın Müdafaası, İstanbul: Yeni Asya.

Ataman, M. \& Kuşcu, Y. (2012). Suûdî Arabistan'daki Siyasal Ve Toplumsal Hareketlerin Gelişimini Etkileyen Faktörler, Alternatif Politika, Cilt. 4, Sayı. 1, s. 1-26.

Ayhan, V. (2009). "HAMAS: Filistin Direnişinde Politik İslam" Ortadoğu Etütleri, Cilt 1, Say1 1, s. 99-134.

Berk, B. (1972). Hakkın Zaferi İçin, İstanbul: Yeni Asya.

Berk, B. (1975). Nurculuk Davası, 3. Bask1, İstanbul: Yeni Asya.

Çakmak, C. (2007). Müslüman Kardeşler Bir Sivil Toplum Örgütü Mü? Akademik Orta Doğu, Cilt 2, Sayı 1.

Dalar, M. (2010). Mısır'da Müslüman Kardeşler Hareketinin Demokrasi Anlayışı ve Sisteme Etkisi, Alternatif Politika, Özel Sayı 1, 48-73.

Davutoğlu, A. (1995). "Bediüzzaman Ve 20. Yüzyılda İslâm Dünyasının Siyasası," 3. Uluslararası Bediüzzaman Said Nursi Sempozyumu, 24-26 Eylül, 1995, İstanbul.

Ganim, İ.B. (1997). Hasen Ahmed Abdurrahmân el-Bennâ, İstanbul: TDV İslâm Ansiklopedisi içinde, Cilt: 16; s. 307-310.

İnayet, H. (2008). Çağdaş İslamî Siyasî Düşünce, Cömert, Y.Z. (Çev.). Ankara: Hece.

Kırkınc1, M. (2010). İhvan-1 Müslimin İleri Gelenleri İle Görüşme, http://www.mehmedkirkinci.com/

Kırkınc1, M. (1985). Darü'l Harb Nedir? İstanbul: Cihan.

Kutay, C. (1980). Çağımızda Bir Asrı Saadet Müslümanı: Bediüzzaman Said Nursi, İstanbul: Yeni Asya.

Mardin, Ş. (1992). Bediüzzaman Said Nursi Olayl; Modern Türkiye'de Din ve Toplumsal Değişim, Çulhaoğlu M. (Çev.). İstanbul: İletişim.

Meriç, C. (1978). Măgaradakiler, İstanbul: Ötüken Neşriyat

Mürsel, S. (1976). Devlet Felsefesi, İstanbul: Yeni Asya.

Nursi, B. S. (19601). Hutbe-i Şamiye, İstanbul: Sinan Matbaas1.

Nursi, B. S. (19602). Divanı Harbi Örfi, Hakikat, 26 Şubat 1324, Dini Ceride No:70. İstanbul: Sinan Matbaas1.

Nursi, B. S. (19603), Emirdağ Lahikast-2, İstanbul: Sinan Matbaas1.

Nursi, B. S. (1991), Münazarat, İstanbul: Yeni Asya Neşriyat.

Nursi, B. S. (1994). Tarihçe-i Hayat, İstanbul: Yeni Asya Neşriyat.

Nursi, B. S. (2006). Sünuhat, Tuluat, İ̧arat, İstanbul: rnk Neşriyat. 
Osman F. (1991). İhvan - İslam ve Demokrasi, İstanbul: Endülüs Yayınları.

Tığlı, İ. (2011). Misır'da Sosyal Hareketler Kifaye Hareketi ve Müslüman Kardeşler, Dünya Bülteni Araştırma Masası, İstanbul.

Türk Demokrasi Vakfı (1992). Demokrasi Nedir? Köker L. (Çev.). Ankara: Yetkin.

Ünlüsoy, K. (2016). Mısır Selefiliği ve İhvân-1 Müslimîn'le İlişkisi, e-Makalât Mezhep Araştırmalarl, 9/1, s. 39-75.

Yeni Türk Ansiklopedisi (1985), Bediüzzaman Said Nursi, 9. Cilt, s. 3345-3351, İstanbul: Ötüken Neşriyat,

Şapka İktisası Hakkında Kanun, Resmî Ceride ile neşir ve ilâm: 22.12.1341, Sayı: 230, No: 871. 